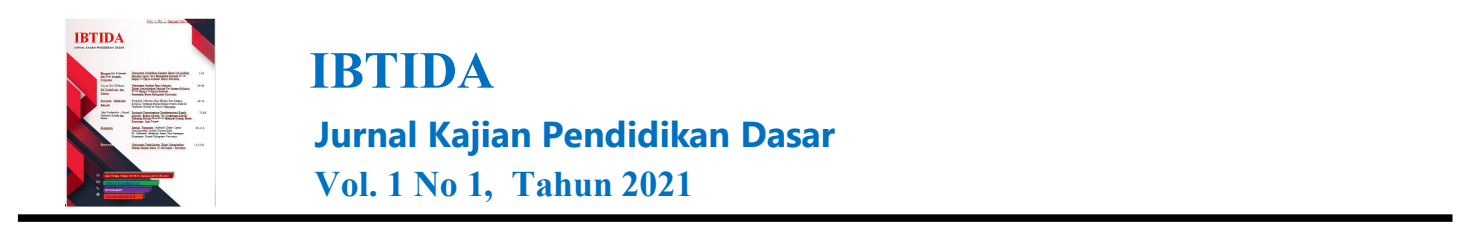

\title{
MANAJEMEN SUMBER DAYA MANUSIA DALAM MENINGKATKAN MOTIVASI DAN SUASANA RELIGIUS DI MI GUPPI AT-TAQWA KETOSARI KECAMATAN BENER KABUPATEN PURWOREJO
}

\author{
Yuyun Dwi Pilihani \\ (MI Guppi At-Taqwa Ketosari) \\ Siti Nurlailiyah
(MTs N 8 Kebumen)
nurlailiyah.siti@gmail.com
}

\author{
Yakino \\ (MTs N 7 Kebumen) \\ yakino@rocketmail.com
}

\begin{abstract}
ABSTRAK
Penelitian ini didasari oleh pentingnya manajemen sumber daya manusia dalam suatu madrasah.Sehubungan dengan hal tersebut, penelitian ini bertujuan untuk mengetahui Manajemen Sumber Daya Manusia dalam Meningkatkan Motivasi dan Suasana Religius di MI GUPPI AT-TAQWA Ketosari Kecamatan Bener Kabupaten Purworejo. Penelitian ini merupakan penelitian kualitatif. Pengumpulan data menggunakan wawancara, observasi, dan dokumentasi, dan keabsahan data menggunakan triangulasi, dan teknik analisis data meliputi pegumpulan data, reduksi data, penyajian data, dan penarikan kesimpulan. Penelitian ini menghasilkan lima kesimpulan: (1) Penarikan SDM dalam Meningkatkan Motivasi dan Suasana Religius di MI Guppi At-Taqwa Desa Ketosari Kecamatan Bener Kabupaten Purworejo belum maksimal. Dalam merekrut tenaga pendidikan masih menggunakan cara-cara sederhana dan masih menggunakan cara-cara lama. (2) Seleksi SDM dalam Meningkatkan Motivasi dan Suasana Religius di MI Guppi At-Taqwa Desa Ketosari Kecamatan Bener Kabupaten Purworejo dilakukan melalui: Penerimaan pendahuluan pelamar, Tes-tes penerimaan, Wawancara seleksi, Pemeriksaan referensi, dan Evaluasi medis, Wawancara atasan langsung, dan Keputusan penerimaan. (3) Pengembangan SDM dalam Meningkatkan Motivasi dan Suasana Religius di MI Guppi At-Taqwa Desa Ketosari Kecamatan Bener Kabupaten Purworejo dilakukan dengan mengadakan pelatihan dan pembinaan untuk senantiasa belajar dan mengembangkan kompetensi diri madrasah. Selain itu juga melalui: Penilaian prestasi kerja, Bimbingan dan konseling, Pembinaan kedisiplinan, dan Pelatihan. (4) Pemeliharaan SDM dalam Meningkatkan Motivasi dan Suasana Religius di MI Guppi At-Taqwa Desa Ketosari Kecamatan Bener Kabupaten Purworejo dilakukan melalui beberapa hal, di antaranya yaitu: pemberian kompensasi, pelayanan karyawan, keamanan dan keselamatan. Itu semua diperhatikan oleh madrasah guna pemeliharaan hubungan kerja yang baik.(5) Penggunaan SDM dalam Meningkatkan Motivasi dan Suasana Religius di MI Guppi At-Taqwa Desa Ketosari Kecamatan Bener Kabupaten Purworejodi antaranya: Perencanaan karir dan Perluasan pekerjaan. Selain itu juga dengan memberikan peluang seluas-luasnya kepada karyawan untuk mengembangkan berbagai macam
\end{abstract}


karier untuk mencapai rencana-rencana mereka untuk lebih maju dan bisa bersaing di masa yang akan datang.

Kata kunci:Manajemen Sumber Daya Manusia, Motivasi, dan Suasana Religius.

\section{PENDAHULUAN}

Manajemen Pendidikan pada era reformasi saat ini merupakan salah satu bentuk implementasi dari Undang-undang Nomor 20 Tahun 2003 tentang Sistem Pendidikan Nasional, yang memberikan arahan untuk dilakukan pengelolaan pada sistem pendidikan di Indonesia, khususnya untuk pengelolaan satuan pendidikan anak usia dini, pendidikan dasar dan menengah menggunakan prinsip standar pelayanan minimal serta didukung dengan manajemen berbasis sekolah. Program pendidikan Indonesia diimplementasikan pada pembangunan lima pilar pendidikan, yaitu meningkatkan ketersediaan layanan pendidikan, meningkatkan keterjangkauan layanan pendidikan, meningkatkan kualitas atau mutu dan relevansi layanan pendidikan, meningkatkan kesetaraan dalam memperoleh layanan pendidikan dan meningkatkan kepastian atau keterjaminan memperoleh layanan pendidikan. Pada hakikatnya kelima pilar tersebut saling terkait satu sama lain, akan tetapi aspek penjaminan mutu pendidikan menjadi faktor atau pilar yang cukup dominan dalam kegiatan manajemen pendidikan.

Mutu Pendidikan Nasional akan terukur lewat ketercapaian segenap Standar Nasional Pendidikan, meliputi standar isi, proses, kompetensi kelulusan, pendidik dan tenaga kependidikan, sarana dan prasarana, pengelolaan, pembiayaan dan penilaian pendidikan. ${ }^{1}$ Perhatian yang serius dan sungguhsungguh oleh para pihak terhadap upaya pemenuhan dan perwujudan segenap standar tersebut akan menentukan kualitas/mutu pendidikan.

Manajemen sumber daya manusia (Human Resource Management) dalam rangka meningkatkan kualitas pendidikan adalah sangat penting artinya. Hal ini mengingat bahwa dalam suatu organisasi atau lembaga pendidikan, dapat maju dan berkembang dengan dukungan dari sumber daya manusia. Oleh karena itu setiap lembaga pendidikan atau organisasi yang ingin berkembang, maka harus memperhatikan sumber daya manusia dan mengelolanya dengan baik, agar tercipta pendidikan yang berkualitas. Keberhasilan pendidikan di sekolah sangat ditentukan oleh keberhasilan kepala sekolah dalam mengelola tenaga kependidikan yang tersedia di sekolah. Dalam hal

\footnotetext{
${ }^{1}$ Peraturan Pemerintah No 19 Tahun 2005 tentang Standar Nasional Pendidikan.
} 
ini, peningkatan produktivitas dan prestasi kerja dapat dilakukan dengan meningkatkan perilaku tenaga kependidikan atau sumber daya manusia di sekolah melalui aplikasi berbagai konsep dan teknik manajemen personalia. Dalam manajemen sumber daya manusia, kepala sekolah merupakan kunci keberhasilan untuk mencapai kualitas pendidikan. Kepala sekolah dituntut untuk senantiasa berusaha membina dan mengembangkan sumber daya manusia atau tenaga pendidik guna menciptakan pendidikan yang berkualitas. $^{2}$

Kebijakan tentang pengelolaan pendidikan tersebut dijelaskan menggunakan produk hukum berupa Peraturan Pemerintah No 19 Tahun 2005 tentang Standar Nasional Pendidikan. Sehingga kemudian diterapkan standar minimal yang harus dimiliki pada pengelolaan satuan pendidikan. Standar tersebut meliputi standar isi, standar proses, standar kompetensi lulusan, standar pendidik dan tenaga kependidikan, standar sarana dan prasarana, standar pengelolaan, standar pembiayaan,dan standar penilaian pendidikan. Delapan standar nasional kemudian dijelaskan melalui peraturan dan petunjuk yang dikeluarkan oleh Kementrian Pendidikan dan Kebudayaan. Agar setiap satuan pendidikan dapat memenuhi kedelapan standar tersebut diperlukan proses evaluasi, akreditasi dan sertifikasi. Tujuannya adalah agar diketahui pencapaian mutu pengelolaan satuan pendidikan sesuai dengan kriteria yang telah ditetapkan.

Kebijakan tentang Standar Nasional Pendidikan tersebut kemudian digunakan sebagai acuan dalam penyusunan pedoman yang lebih operasional, yaitu kebijakan tentang standar pengelolaan pendidikan melalui Permendiknas Nomor 19 Tahun 2007 Tentang Standar Pengelolaan Pendidikan. Pada hakikatnya kebijakan tersebut merupakan penjabaran sekaligus bentuk operasionalisasi dari peraturan tentang Standar Nasional Pendidikan (SNP) dan UU SPM (Standar Pelayanan Mutu). Setiap satuan pendidikan diharuskan untuk mengikuti serta memenuhi hal-hal yang terdapat pada Standar Pengelolaan Pendidikan sebagai rujukan dalam mengelola satuan pendidikan masing-masing. Secara umum standar pengelolaan pendidikan memberikan arahan sekaligus bentuk dari manajemen pendidikan atau manajemen berbasis sekolah. Pengelolaan pendidikan di sekolah terdiri dari perencanaan program, pelaksanaan

\footnotetext{
${ }^{2}$ Yusriani. Implementasi Manajemen Sumber Daya Manusia: Tenaga Pendidik dan Kependidikan untuk Meningkatkan Mutu Layanan Pendidikan. (Al-Ulum. Vol.1 No.1. Th. 2012), hal. 73.
} 
program, evaluasi program, kepemimpinan kepala satuan pendidikan dan sistem informasi manajemen yang digunakan.

Kunci utama agar perencanaan dan program-program pengembangan pendidikan di sekolah berjalan optimal berada di tangan para pendidik dan tenaga kependidikan di sekolah. Dengan demikian jelaslah masalah peningkatan profesionalisme ketenagaan sangatlah penting untuk diperhatikan. Berkaitan dengan hal tersebut di atas, secara rinci telah dituangkan dalam PP 19 Tahun 2005 pasal 28 dan pasal 29 mengenai kualifikasi akademik dan kompetensi yang harus dipenuhi sebagai pendidik. Kompetensi yang harus dipenuhi mencakup empat kompetensi yaitu: (1) Kompetensi pedagogik; (2) Kompetensi kepribadian; (3) Kompetensi profesional; dan (4) Kompetensi Sosial. Ketentuan yang lebih terperinci lagi dijabarkan dalam Permendiknas No. 16 Tahun 2007 yaitu tentang Kualifikasi Akademik dan Kompetensi Guru. Mengenai tugas guru dijelaskan dalam UU No 14 Tahun 2005 pasal 1 sebagai berikut : "Guru adalah pendidik profesional dengan tugas utama mendidik, mengajar, membimbing, mengarahkan, melatih, menilai, dan mengevaluasi peserta didik." Ketentuan ini semestinya dapat mendorong dan memacu para guru untuk dapat menyandang gelar dan layak dengan setatus sebagai tenaga profesional.

Profesional adalah pekerjaan atau kegiatan yang dilakukan oleh seseorang dan menjadi sumber penghasilan kehidupan yang memerlukan keahlian, kemahiran, atau kecakapan yang memenuhi standar mutu atau norma tertentu serta memerlukan pendidikan profesi.Perlu disadari pula bahwa untuk dapat berlangsungnya kegiatan pendidikan di sekolah, unsur manusia merupakan unsur yang sangat penting, karena kelancaran pelaksanaan program-program sekolah tergantung kepada orangorang yang melaksanakannya. Dengan demikian, hal tersebut harus betul-betul disadari oleh semua personil sekolah, sehingga dengan segala kemampuannya dengan bimbingan kepala sekolah akan terus berupaya mengelola sumber daya yang ada untuk pengembangan sekolah.

Kualitas sumber daya manusia masih menjadi persoalan utama dalam bidang pendidikan di Indonesia, baik di tingkat pendidikan tinggi maupun pendidikan dasar dan menengah. Dari sekitar 160.000 dosen yang ada di Indonesia, hampir 54 persennya masih belum S2 dan S3. Sementara guru, dari 2,7 juta guru, 1,5 juta di antaranya belum $\mathrm{S} 1$. Dengan kata lain untuk memperoleh tenaga pendidik dan tenaga kependidikan yang 
bermutu diperlukan manajemen sumber daya manusia. Hal ini penting sekali karena semua sumber daya yang ada di sekolah yang mencakup man, material, and money tanpa unsur ketenagaan yang bermutu sangat berat untuk dapat mencapai pendidikan yang bermutu. ${ }^{3}$

Usaha untuk meningkatkan kualitas pendidikan mulai dilakukan oleh pemerintah lewat beberapa usaha seperti program sertifikasi guru dan dosen yang menuntut agar minimal guru berkualifikasi S1 dan D4, sedangkan dosen minimal berkualifikasi S2 atau S3. Mereka juga harus mempunyai kompetensi dalam bidang ilmiah, didaktik, komunikasi dengan siswa dan kepribadian. Selanjutnya beberapa pembenahan gedung sekolah dan pembaruan kurikulum yang lebih menekankan siswa dan mahasiswa aktif belajar juga dilakukan oleh pemerintah untuk mencapai standar minimal tertentu, standardisasi pendidikan dan lain-lain.

Dalam upaya memperbaiki dan meningkatkan mutu pendidikan banyak agenda reformasi yang telah, sedang, dan akan dilaksanakan seperti penataan udang-undang pendidikan nasional dan berbagai perundang-undangan lainnya. Berbagai program inovatif sebagai upaya reformasi pendidikan antara lain penerapan pendekatan BBE (Broad Base Education) atau pendidikan berbasis luas, pendidikan berorientasi keterampilan hidup (life skill), pendidikan untuk semua, KBK, MBS, Dewan Pendidikan, Ujian Akhir Nasional, Sekolah Standar Nasional (SSN), dan penilaian Portofolio. $^{4}$

Selain usaha pemerintah tersebut di atas, Isjoni menyatakan bahwa guru memiliki peran yang sangat penting dalam menentukan kualitas dan kuantitas pengajaran yang dilaksanakan. ${ }^{5}$ Oleh sebab itu, guru harus memikirkan dan membuat perencanaan secara seksama dalam meningkatkan kesempatan belajar bagi siswanya dan memperbaiki kualitas mengajarnya. Hal ini menuntut perubahan-perubahan dalam pengorganisasian kelas, penggunaan metode mengajar, strategi belajar-mengajar, maupun siskap dan karakteristik guru dalam mengelola proses belajar-mengajar.

Suasana religius merupakan penciptaan suasana atau iklim kehidupan keagamaan yang dampaknya ialah berkembangnya suatu pandangan hidup yang bernafaskan atau dijiwai oleh ajaran dan nilai-nilai agama yang diwujudkan dalam sikap hidup serta

\footnotetext{
${ }^{3} \mathrm{lbid}$, hal. 70.

${ }^{4}$ Isjoni. Pembelajaran Kooperatif. (Pekanbaru: Pustaka Pelajar, 2009), hal. 80.

${ }^{5}$ Ibid, hal. 11.
} 
ketrampilan hidup oleh para warga sekolah dalam kehidupan mereka sehari-hari. Sedangkan konteks pendidikan agama ada yang bersifat vertikal dan horizontal. Yang vertikal berwujud hubungan manusia atau warga sekolah dengan Allah swt. Penciptaan suasana religius yang bersifat vertikal dapat diwujudkan dalam kegiatan-kegiatan ritual, seperti shalat berjamaah, do'a bersama ketika akan dan telah meraih sukses tertentu, menegakan komitmen dan loyalitas terhadap moral force disekolah dan lain-lain. Yang horizontal berwujud hubungan antar manusia atau antar warga sekolah, dan hubungan mereka dengan alam sekitarnya. Penciptaan suasana religius yang bersifat horizontal lebih mendudukan sekolah sebagai institusi sosial, yang jika dilihat dari struktur hubungan antar manusianya, dapat diklasifikasikan ke dalam tiga hubungan, yaitu: (1) hubungan antara atasan dan bawahan; (2) Hubungan profesional; dan (3) Hubungan sederajat atau sukarela. ${ }^{6}$

Untuk menciptakan masing-masing hubungan agar tercipta kerjasama yang harmonis dan seimbang, maka diperlukan adanya pengertian dan saling menghormati. Pada tataran hubungan atasanbawahan perlu adanya kepatuhan dan loyalitas para guru dan tenaga kependidikan lainnya terhadap atasannya misalnya kepala sekolah. Sedangkan hubungan profesional lebih memfokuskan pada penciptaan hubungan yang rasional, kritis, dinamis antar sesama guru dan pimpinannya untuk saling berdiskusi demi pengembangan akademik, yakni pengembangan dan peningkatan kualitas sekolah.

Adapun hubungan sederajat atau suka rela merupakan hubungan manusiawi antar sejawat, untuk saling membantu, mendo'akan, mengingatkan dan melengkapi antara satu dengan yang lainnya.

Penciptaan suasana yang menyangkut ketiga hubungan tersebut di atas dengan lingkungan atau alam sekitarnya diwujudkan dalam bentuk membangun suasana atau iklim yang komitmen dalam menjaga dan memelihara berbagai fasilitas atau sarana dan prasarana yang dimiliki oleh sekolah, serta menjaga dan memelihara kelestarian, kebersihan dan keindahan ingkungan hidup di sekolah. ${ }^{7}$ Keberagamaan atau religiusitas lebih melihat aspek yang "di dalam lubuk hati nurani” pribadi oleh karena itu, pada dasarnya religiusitas mengatasi atau lebih dalam dari agama yang tampak formal. Yang dicari dan diharapkan untuk anak-anak kita adalah bagaimana mereka dapat tumbuh

\footnotetext{
${ }^{6}$ Muhaimin, Nuansa Baru Pendidikan Islam, (Jakarta: PT Raja Grafindo Persada, 2006), hal. 108.

7 Ibid, hal. 109.
} 
menjadi abdi-abdi Allah yang beragama baik, namun sekaligus orang mendalami cita rasa religiusitasnya, dan yang menyinarkan damai murni karena religiusnya, meskipun dalam bidang keagamaannya kurang patuh. Itu dibandingkan dengan orang yang hebat keagamaannya, tetapi ternyata itu hanya kulit luarnya saja.

Sekolah adalah lembaga formal yang melakukan bimbingan dan binaan pada anak didik terkait dengan pengembangan keberagamaan dirinya. Oleh karena itu perlu adanya suatu upaya penciptaan suasana religius yang dikembangkan pada lembaga sekolah melalui:

1. Model Struktural

Yaitu penciptaan suasana religius yang disemangati oleh adanya peraturanperaturan, pembangunan kesan, bak dunia luar atas kepemimpinan atau kebijakan dari suatu lembaga pendidikan atau suatu organisasi. Model ini biasanya bersifat “top down” yakni kegiatan keagamaan yang dibuat atas prakarsa atau instruksi dari atasan.

2. Model Formal

Yaitu penciptaan suasana religius yang didasari atas pemahaman bahwa pendidikan agama adalah upaya manusia untuk mengajarkan masalah-masalah kehidupan akhirat saja atau kehidupan rohani saja. Model penciptaan suasa religius formal tersebut berimplikasi terhadap pengembangan pendidikan agama yang lebih berorientasi pada ke akheratan. Model ini biasanya menggunakan pendekatan yang bersifat normatif, doktriner, dan absolut.

\section{Model Mekanik}

Model mekanik dalam penciptaan suasana religius adalah penciptaan suasana yang didasari oleh pengalaman bahwa kehidupan terdiri atas berbagai aspek dan pendidikan dipandang sebagaipenamaan dan pengembangan seperangkat nilai kehidupan, yang masing-masing bergerak dan berjalan menurut fungsinya.

\section{Model Organik}

Yaitu penciptaan suasana religius yang disemangati oleh adanya pandangan bahwa pendidikan agama adalah kesatuan dari berbagai sistem yang berusaha 
mengembangkan pandangan atau semangat hidup agamis, yang dimanifestasikan dalam sikap hidup yang religius. ${ }^{8}$

Dengan beracuan pada empat model pengembangan Susana religius di sekolah kepala sekolah sebagai leader yang memegang kunci dalam administrasi dan pembelajaran harus mampu menggerakkan kegiatan-kegiatan dengan mengoptimalkan SDM yang ada dalam rangka memotivasi peningkatan dan penanaman suasana religus dengan melakukan inovasi pada bidang metode pengajaran, teknik mengajar, strategi pembelajaran dan mencobakan ide-ide baru yang dapat diperkirkan dapat meningkatkan motivasi dan penciptaan susana religius.

Berdasarkan latar belakang di atas, maka perlu dilakukan analisis Manajemen Sumber Daya Manusia dalam Meningkatkan Motivasi dan Suasana Religius di MI GUPPI ATTAQWA Desa Ketosari Kecamatan Bener Kabupaten Purworejo.

\section{KAJIAN LITERATUR}

\section{Manajemen Sumber Daya Manusia}

"Management is attainment of organizational goals in an effective and efficient manner through planning, organizing, leading, and controlling organizational resources". 9 Selanjutnya, menurut Stoner dan Freeman (Silalahi), "Management is the process of planning, organizing, leading, and controlling the work of organization members and using all available organizational resources to reach stated organizational goals". ${ }^{10}$ Sedangkan Manullang mengemukakan: "Seni dan ilmu pengadaan, pengembangan dan pemanfaatan SDM sehingga tujuan perusahaan dapat direalisasikan secara daya guna kegairahan kerja dari semua pekerjaan". ${ }^{11}$

Berdasarkan pengertian para ahli di atas, maka dapat disimpulkan bahwa manajemen adalah proses untuk mencapai tujuan-tujuan organisasi dengan melakukan kegiatan kerja dari empat fungsi utama yaitu merencanakan (planning), mengorganisasikan (organizing), memimpin (leading), dan mengendalikan (controlling). Dengan demikian, manajemen adalah suatu kegiatan yang berkesinambungan. Untuk mencapai efisiensi serta efektivitas dalam manajemen, maka segala tindakan dan kegiatan baru baiknya dilaksanakan dengan pertimbangan dan

\footnotetext{
8 Ibid, hal. 305-307.

${ }^{9}$ Daft, Richard L, Era Baru Manajemen, Edisi 9, Buku 2, (Jakarta: Salemba Empat, 2010), hal. 4.

${ }^{10}$ Silalahi, Ulber, Pemahaman praktis azas-azas manajemen. (Bandung: Mandar Maju, 2002), hal. 4.

${ }^{11}$ Manullang, M., Manajemen Sumber Daya Manusia. (Jakarta: Ghalia Indonesia, 2012), hal. 198.
} 
perhitungan yang rasional. Untuk itu diperlukan langkah-langkah kegiatan dengan perumusan secara jelas dan tegas, agar tujuan program yang dimaksudkan dapat berjalan dengan sebaik mungkin.

Manajemen SDM adalah rangkaian strategis, proses dan aktivitas yang di desain untuk menunjang tujuan perusahaan dengan cara mengintegrasikan kebutuhan perusahaan dan individunya. ${ }^{12}$ Dessler mendefinisikan manajemen sumber daya manusia sebagai kebijakan dan praktik menentukan aspek manusia atau sumber daya manusia dalam posisi manajemen, termasuk merekrut, menyaring, melatih, memberi penghargaan dan penilaian. ${ }^{13}$

Dari beberapa pendapat diatas, dapat menarik kesimpulan bahwa manajemen sumber daya manusia merupakan ilmu dan seni yang di dalamnya terkandung fungsi fungsi manajerial dan operasional yang ditujukan agar sumber daya manusia dapat dimanfaatkan seefektif dan seefisien mungkin untuk mencapai sasaran yang ditetapkan. Dengan perencanaan sumber daya manusia dapat menentukan kebutuhan akan tenaga kerja berdasarkan peramalan, pengembangan, pengimplementasian, dan pengontrolan kebutuhan tersebut yang berintegrasi dengan rencana organisasi agar tercipta jumlah pegawai, penempatan pegawai secara tepat dan bermanfaat secara ekonomis.

Menurut T. Hani Handoko, "Manajemen Sumber Daya Manusia adalah penarikan, seleksi, pengembangan, pemeliharaan, dan penggunaan sumber daya manusia untuk mencapai baik tujuan-tujuan individu maupun organisasi." 14

Rekrutmen merupakan suatu proses mencari, mengadakan, menemukan dan menarik para pelamar untuk dipekerjakan dalam suatu organisasi. Singodimejo menyatakan bahwa rekrutmen merupakan "proses mencari, menemukan, dan menarik para pelamar untuk dipekerjakan dalam organisasi". ${ }^{15}$ Menurut Mathis dan Jackson, rekrutmen adalah proses mengumpulkan sejumlah pelamar yang berkualifikasi bagus untuk pekerjaan di dalam organisasi. ${ }^{16}$

\footnotetext{
12 Rivai, Veithzal dan Ella Jauvani Sagala, Manajemen Sumber Daya Manusia untuk Perusahaan. Edisi Kedua, (Jakarta: Raja Grafindo Persada, 2009), hal. 1.

${ }^{13}$ Dessler, Gary, Manajemen sumber daya manusia. (Jakarta: Indkes, 2011), hal. 5.

${ }^{14}$ Handoko, T. Hani, Manajemen. Edisi Kedua. (Yogyakarta: BPFE Yogyakarta, 2014), hal. 4.

${ }^{15}$ Singodimejo, M, Manajemen Sumber Daya Manusia, (Surabaya: SMMAS, 2000), hal. 45.

${ }_{16}$ Mathis, R.L. \& J.H. Jackson. Human Resource Management: Manajemen Sumber. Daya Manusia. Terjemahan Dian Angelia. (Jakarta: Salemba Empat, 2001), hal. 273.
} 
Riva'i menjelaskan bahwa, seleksi adalah kegiatan dalam manajemen SDM yang dilakukan setelah proses rekrutmen selesai dilaksanakan. ${ }^{17}$ Hal ini berati telah terkumpul sejumlah pelamar yang memenuhi syarat untuk kemudian dipilih mana yang dapat ditetapkan sebagai karyawan dalam suatu perusahaan. Proses pemilihan ini yang dinamakan dengan seleksi. Selanjutnya, menurut Simamora, seleksi adalah proses pemilihan dari sekelompok pelamar yang paling memenuhi kriteria seleksi untuk posisi yang tersedia dalam sebuah perusahaan. ${ }^{18}$

Pengembangan sumber daya manusia sangat berkaitan erat dengan ketercapaian yang ingin diraih, efektivitas, produktivitas dan kebutuhan akan kepuasan tenaga kerja. Pengembangan SDM ditujukan untuk membantu setiap karyawan untuk mengatasi dan menjawab permasalahan di masa datang dengan memperhatikan tugas dan kewajibannya yang dihadapi sekarang. ${ }^{19}$ Oleh sebab itu, dilihat dari fungsinya pengembangan SDM merupakan upaya dalam bentuk pelatihan dan pengembangan, pengembangan organisasi serta pengembangan karir. Usaha-usaha untuk meningkatkan mutu serta efisien seluruh tenaga yang berada dalam suatu unit organisasi, baik tenaga menagerial, tenaga teknis edukatif maupun tenaga tatausaha memenuhi syarat jabatan yang ada sekarang dan untuk masa yang akan dating. ${ }^{20}$

Dalam pemeliharaan SDM diperlukan pemberian kompensasi, hubungan perburuhan, pelayanan karyawan, keamanan dan kesehatan. Dalam pemberian kompensasi diperlukan evaluasi pekerjaan, pengupahan, program-program intensif, dan kompensasi lengkap (tringe benefits). Dalam hubungan perburuhan perlu perundingan kolektif dan perjanjian kerja. Dalam pelayanan karyawan perlu ada rekreasi atau hiburan, pelayanan "on-the-job" dan "off-the-job".

Penggunaan SDM berarti memanfaatkan SDM sesuai kebutuhan organisasi. Penggunaan SDM meliputi perencanaan karier, perluasan pekerjaan / promosi, dan audit personalia. ${ }^{21}$ Kegiatan manajemen SDM perlu dilakukan secara baik. Bila kegiatankegiatan manajemen SDM tidak memuaskan kebutuhan-kebutuhan karyawan secara sukses, karyawan mungkin berkumpul dan melakukan kegiatan kolektif. Hal tersebut mengakibatkan manajemen SDM dihadapkan pada situasi baru, yaitu hubungan serikat

\footnotetext{
${ }^{17}$ Rivai, Veithzal, Op. Cit., hal. 159.

${ }^{18}$ Simamora. Manajemen Sumber daya Manusia, (Jakarta: Lentera, 2004).

${ }^{19}$ Rivai, Veithzal, Op. Cit., hal. 22.

${ }^{20}$ Sismiati Atiek \& Rugaiyah, Profesi Kependidikan, (Bogor: Ghalia Indonesia, 2011), hal. 80.

${ }^{21}$ Handoko, T. Hani, Op. Cit., hal. 8.
} 
karyawan manajemen. Oleh karena itu, untuk menanggapi "tuntutan-tuntutan kolektif para karyawan, maka fungsi personalia perlu merundingkan dan mengadministrasikan suatu perjanjian kerja.

\section{Konsep Motivasi}

Motivasi adalah "pemberian daya penggerak yang menciptakan kegairahan kerja seseorang, agar mereka mau bekerja keras, bekerja efektif dan terintegritasi dengan segala daya upaya untuk mencapai kepuasan". 22 Sedangkan menurut Bernard (Sedarmayanti), motivasi adalah "kondisi mental yang mendorong aktivitas dan memberi energy yang mengarah kepada pencapaian kebutuhan, memberi kepuasan atau mengurangi ketidakseimbangan", ${ }^{23}$ Motivasi kerja merupakan dorongan atau keinginan yang berasal dari dalam maupun luar diri seseorang untuk melakukan suatu pekerjaan atau upaya-upaya guna memenuhi kebutuhan individu ataupun organisasinya.

Untuk meningkatkan semangat kerja seseorang, pemberian motivasi juga memiliki tujuan yang lain. Menurut Hasibuan mengungkapkan bahwa: (a) Mendorong gairah dan semangat kerja karyawan; (b) Meningkatkan moral dan kepuasan karyawan; (c) Meningkatkan produktivitas kerja karyawan; (d) Mempertahankan loyalitas dan kestabilan karyawan; (e) Meningkatkan kedisipilan dan menurunkan tingkat absensi karyawan; (f) Mengefektifkan pengadaan karyawan; (g) Menciptakan suasana dan hubungan kerja yang baik; (h) Meningkatkan kreativitas dan partisipasi karyawan; (i) Meningkatkan kesejahteraan karyawan; (j) Mempertinggi rasa tanggung jawab karyawan terhadap tugas-tugasnya; (k) Meningkatkan efisiensi penggunaan alat-alat dan bahan baku. ${ }^{24}$

Dari pendapat di atas telah jelas bahwa betapa pentingnya peran motivasi bagi karyawan ataupun organisasi. Tujuan pemberian motivasi bagi pegawai bukan hanya untuk meningkatkan semangat kerja pegawai saja, namun juga memiliki tujuan lain seperti meningkatnya gairah kerja, kepuasan kerja, produktivitas kerja, kedisiplinan kerja, hubungan kerja yang baik, kreativitas, loyalitas karyawan, kesejahteraan, rasa tanggung jawab, dan efisiensi penggunaan alat-alat kerja, sedangkan tujuan motivasi

\footnotetext{
${ }^{22}$ Hasibuan, Manajemen Sumber Daya Manusia, (Jakarta: Bumi Aksara, 2011), hal. 95.

${ }^{23}$ Sedarmayanti, Sumber Daya Manusia dan Produktivitas Kerja, (Bandung: Mandar Maju, 2009), hal. 66.

${ }^{24}$ Hasibuan, Op. Cit., hal. 218.
} 
bagi organisasi adalah meningkatkan produktivitas dan efisiensi organisasi, merubah perilaku karyawan sesuai keinginan perusahaan, dan menumbuhkan loyalitas karyawan terhadap perusahaan, sehingga diharapkan tujuan dari lembaga ataupun organisasi dapat tercapai sesuai harapan.

\section{Suasana Religius}

Secara etimologi, apabila ditelusuri dari asal katanya, kata religius berasal bahasa Inggris religion yang artinya agama atau religious yang artinya beragama. Percaya kepada Allah yang menguasai alam semesta serta semua yang ada di dalamnya, hal ihwal agama. Segala sesuatu yang berhubungan dengan agama. Sedangkan Secara terminologi, religius dimaknai keadaan dalam diri seseorang yang mendorongnya untuk bertingkah laku sesuai kadar ketaatannya terhadap agama. Keseluruhan tingkah laku manusia yang terpuji yang dilaksanakan untuk memperoleh ridha Allah.Agama meliputi keseluruhan tingkah laku itu membentuk keutuhan manusia berbudi luhur (akhlaqul karimah), atas dasar percaya atau iman kepada Allah dan tanggungjawab pribadi di hari kemudian. ${ }^{25}$

Religiusitas merupakan sikap batin seseorang ketika mengalami langsung realitas kehidupan dirinya mulai dari kelahiran, kehidupan, bencana, nikmat, dan kematian. ${ }^{26}$ Perilaku religius dapat dikembangkan di sekolah melalui pembiasaan. Di antaranya adalah berdoa ketika hendak dan seusai belajar. Hal ini kelihatannya ringan, akan tetapi kalau tidak ada pembiasaan, maka juga tidak akan dilakukan oleh peserta didik.

Nilai pembentukan karakter pada manusia dikatakan sebagai nilai religius itu sendiri. Nilai religius itu sangat penting karena corak keberagaman manusia tergantung pada nilai religius itu sendiri. Manusia yang memiliki karakter merupakan indikator manusia yang religius. ${ }^{27}$

Dalam konteks pendidikan di sekolah berarti penciptaan suasana atau iklim kehidupan keagamaan yang dampaknya ialah berkembangnya suatu pandangan hidup yang bernafaskan atau dijiwai oleh ajaran dan nilai-nilai agama yang diwujudkan dalam sikap hidup serta ketrampilan hidup oleh para warga sekolah dalam kehidupan mereka sehari-hari.

\footnotetext{
${ }^{25}$ Nurcholish Madjid, Masyarakat Religius. (Jakarta: Dian Rakyat, 2010), hal. 34.

${ }^{26}$ Indah Ivonna, dkk, Pendidikan Budi Pekerti, (Yogyakarta: Kanisius, 2013), hal. 17.

${ }^{27}$ Ngainun Naim, Character Building. (Yogyakarta: Arruz Media, 2012), hal. 124.
} 
Sedangkan konteks pendidikan agama ada yang bersifat vertikal dan horizontal. Yang vertikal berwujud hubungan manusia atau warga sekolah dengan Allah swt. Penciptaan suasana religius yang bersifat vertikal dapat diwujudkan dalam kegiatankegiatan ritual, seperti shalat berjamaah, do'a bersama ketika akan dan telah meraih sukses tertentu, menegakan komitmen dan loyalitas terhadap moral force disekolah dan lain-lain. Yang horizontal berwujud hubungan antar manusia atau antar warga sekolah, dan hubungan mereka dengan alam sekitarnya. Penciptaan suasana religius yang bersifat horizontal lebih mendudukan sekolah sebagai institusi sosial, yang jika dilihat dari struktur hubungan antar manusianya, dapat diklasifikasikan ke dalam tiga hubungan, yaitu: (a) Hubungan antara atasan dan bawahan; (b) Hubungan profesional; dan (c) Hubungan sederajat atau suka rela.

Untuk menciptakan masing-masing hubungan agar tercipta kerjasama yang harmonis dan seimbang, maka diperlukan adanya pengertian dan saling menghormati. Pada tataran hubungan atasan bawahan perlu adanya kepatuhan dan loyalitas para guru dan tenaga kependidikan lainnya terhadap atasannya misalnya kepala sekolah.

Suasana religius yang diharapkan dalam berbagai jenjang pendidikan adalah bagaimana anak-anak dapat tumbuh sebagai abdi-abdi Allah yang beragama baik, sekaligus mempunyai cita rasa religius yang mendalam, serta menyinarkan damai murni karena fitrah religiusnya.

Pengelolaan sumber daya manusia berarti membahas aspek manusia selaku pengelola pendidikan, yang menyangkut hubungan antara kepala madrasah, Guru dan Karyawan. Kepala Madrasah selaku pimpinan dituntut kemampuannya untuk memimpin lembaganya dengan baik dan penuh tanggung jawab. Untuk menciptakan kerjasama yang efektif, kepala madrasah hendaknya di dalam mengadakan pembagian tugas dan tanggung jawab di antara para personal pendidikan disesuaikan dengan tingkat kemampuan dan keterampilannya, sebab pemberian tugas yang tidak sesuai akan berdampak tidak baik.

Upaya penciptaan suasana religius di sekolah, menurut Muhaimin, dimulai dengan mengadakan berbagai kegiatan keagamaan yang pelaksanaannya ditempatkan dilingkungan sekolah. Sifat pelaksanaan kegiatan tersebut untuk pertama-tama dapat dilakukan secara "top down" kemudian pada masa-masa berikutnya diupayakan berjalan secara "bottom up" dan pada akhirnya diharapkan menjadi tradisi bagi sivitas sekolah. 
Aktivitas keagamaan seperti khatmil qur'an dan istighosah serta kegiatan yang sejenis dirasa dapat menciptakan suasana ketenangan dan kedamaian di kalangan sivitas akademika sekolah. ${ }^{28}$

Di dalam penciptaan suasana religius di sekolah tidak pernah lepas dari peran dan tanggung jawab seorang kepala sekolah. Karena orang pertama yang mempunyai kewajiban dalam meningkatkan segala hal yang berkaitan dengan sekolah yaitu kepala sekolah. Kepala sekolah harus dapat menjadi inovator dan mempunyai upaya-upaya dalam meningkatkan serta menciptakan hak-hak baru dalam suasana religius di sekolah yang dipimpinnya.

\section{METODE PENELITIAN}

Jenis penelitian ini yaitu kualitatif, pendekatan yang lebih menekankan pada aspek pemahaman secara mendalam terhadap suatu masalah manusia dan sosial. Waktu penelitian adalah antara 1 Januari 2019 sampai dengan 1 Juli 2019, dan tempat penelitian adalah di MI Guppi At-Taqwa Ketosari, Bener, Purworejo.

Subjek dan informan penelitian ini yaitu orang-orang yang berhubungan dengan manajemen sumber daya manusia dalam meningkatkan motivasi dan suasana religius: kepala sekolah, guru kelas, staf, siswa, wali siswa, komite madrasah, dan alumni MI Guppi At-Taqwa Ketosari, Bener, Purworejo.

Teknik pengumpulan data merupakan cara yang digunakan peneliti untuk memperoleh data penelitian yang dibutuhkan. Proses pengumpulan data dalam penelitian ini dilakukan dengan: observasi, wawancara mendalam, dan dokumentasi.

Dalam menguji keabsahan data peneliti menggunakan tehnik Triangulasi, yakni teknik pemeriksaan keabsahan data yang memanfaatkan sesuatu yang lain diluar data untuk keperluan pengecekan atau sebagai pembanding terhadap data itu.Itu artinya melakukan validasi, dengan cara mengecek dokumen program dan bukti tertulis lainnya. ${ }^{29}$ Dalam penelitian ini menggunakan Triangulasi metode yaitu menggunakan dua strategi yaitu: (1) Pengecekan terhadap derajat kepercayaan penemuan hasil penelitian dengan beberapa tehnik pengumpulan data; (2) Pengecekan derajat kepercayaan beberapa sumber data dengan metode yang sama.

\footnotetext{
${ }^{28}$ Muhaimin, Op. Cit., hal. 298.

${ }^{29}$ Patton, Michael Quinn. Metode Evaluasi Kualitatif. (Yogyakarta: Pustaka Pelajar, 2006), hal. 280.
} 
Langkah-langkah yang dilakukan penulis lakukan untuk menganalisis data yang sudah diperoleh dari hasil observasi, wawancara, dan dokumentasi yaitu dengan menggunakan model analisis data Miles dan Huberman sebagaimana yang dikutip oleh Sugiyono, yaitu reduksi data (data reduction), penyajian data (data display), dan penarikan kesimpulan (conclusion drawing/verification). ${ }^{30}$

\section{HASIL PENELITIAN DAN PEMBAHASAN}

\section{Penarikan SDM dalam Meningkatkan Motivasi dan Suasana Religius di MI GUPPI ATTAQWA Desa Ketosari Kecamatan Bener Kabupaten Purworejo}

Setelah membaca dari berbagai pendapat di atas tentang rekrutmen, bahwa dalam proses rekrutmen sumber daya manusia harus benar-benar dilakukan dengan baik. Karena hasil rekrutmen sangat berpengaruh besar terhadap kualitas mutu pendidikan di masa yang akan datang. Jika dalam rekrutmen tidak dilakukan dengan sungguhsungguh, maka akan terjadi ketidaksamaan antara yang dilakukan dengan yang diperoleh.

Cara-cara yang digunakan dalam pelaksanaan penarikan pegawai di MI Guppi At-Taqwa Ketosari belum maksimal, masih sngat sederhana, karena memang kondisi Madrasah Ibtidaiyah Guppi Attaqwa Ketosari banyak kekurangannya dari berbagai bidang. Terutama dari pembiayaan gaji karyawan.

Menurut Dubois, recruitment is the process of attracting as many qualified applicants as possible for existing vacancies and anticipated openings. It is talent search, a pursuit of the best group of applicants fir an available position. ${ }^{31}$ Rekrutmen adalah proses menarik sebanyak mungkin kualifikasi pelamar untuk lowongan yang ada dan bukan diantisipasi. Ini merupakan pencarian bakat, pengejaran kelompok terbaik pelamar untuk posisi yang tersedia.

Ketertarikan para pelamar untuk masuk menjadi tenaga pendidik atau pegawai di di MI Guppi At-Taqwa Ketosari sangat sedikit. Hal tersebut kemungkinan karena kesejahteraan para pegawai yang masih minim. Untuk itu, perlu usaha keras dalam proses penarikan pegawai baru, guna meningkatkan mutu pendidikan di Madrasah Ibtidaiyah Guppi Attaqwa Ketosari pada tahun depan dan untuk masa yang akan datang.

\footnotetext{
${ }^{30}$ Sugiyono, Metode Penelitian Pendidikan, (Bandung: Alfabeta. 2009), hal. 254.

${ }^{31}$ Dubois, Competency-Based Human Resource Management, (Mountain View, California: Davies-Black Publising, 2004), hal. 96.
} 


\section{Seleksi SDM dalam Meningkatkan Motivasi dan Suasana Religius di MI GUPPI ATTAQWA Desa Ketosari Kecamatan Bener Kabupaten Purworejo}

Seleksi merupakan proses untuk memutuskan calon personil dapat diterima atau tidak. Menurut Rivai'i, menjelaskan bahwa seleksi adalah kegiatan dalam manajemen SDM yang dilakukan setelah proses rekrutmen selesai dilaksanakan. ${ }^{32}$ Hal ini berarti telah terkumpul sejumlah pelamar yang memenuhi syarat untuk kemudian dipilih mana yang dapat ditetapkan sebagai karyawan dalam suatu perusahaan. Proses pemilihan ini yang dinamakan dengan seleksi.

Proses seleksi dilakukan oleh Madrasah Ibtidaiyah Guppi At-Taqwa Ketosari untuk memilih tenaga pendidik terbaik sesuai dengan kriteria yang dibutuhkan madrasah. Selain itu, seleksi juga dilakukan untuk memilih personil yang di promosikan untuk menduduki jabatan baru, perpindakan bagian maupun untuk pemutusan hubungan kerja di sekolah. Dengan demikian, maka sesuai dengan yang dikemukakan Simamora, bahwa seleksi adalah proses pemilihan dari sekelompok pelamar yang paling memenuhi criteria seleksi untuk posisi yang tersedia dalam sebuah perusahaan. ${ }^{33}$

Meskipun proses perekrutan di Madrasah Ibtidaiyah Guppi Attaqwa dilakukan secara sederhana, akan tetapi proses seleksi tetap diadakan. Karena proses seleksi sangat penting dilakukan untuk mendapatkan tenaga pendidik / karyawan sesuai dengan kebutuhan. Proses seleksi adalah langkah-langkah yang harus dilakukan oleh pelamar sampai akhirnya memperoleh keputusan ia di terima atau di tolak sebagai karyawan baru.

\section{Pengembangan SDM dalam Meningkatkan Motivasi dan Suasana Religius di} MI GUPPI ATTAQWA Desa Ketosari Kecamatan Bener Kabupaten Purworejo

Pelatihan (training) diartikan sebagai "activities designed to provide learners with the knowledge and skills neened for their present jobs". Sedangkan pengembangan (development) diartikan sebagai, "learning may looks beyond the knowledge and skill needed for present job". ${ }^{34}$

Pelatihan adalah serangkaian aktivitas yang dirancang untuk meningkatkan keahlian, pengetahuan dan pengalaman, ataupun perubahan sikap individu. Pelatihan

\footnotetext{
${ }^{32}$ Rivai, Veithzal, Op. Cit., hal. 159.

${ }^{33}$ Simamora, Op. Cit.

${ }^{34}$ Mondy R. W \& Shane, R., Management, (New Jersey: Pretince Hill Inc, 1999), hal. 254.
} 
berkenan dengan perolehan keahlian-keahlian atau pengetahuan tertentu. Sedangkan pengembangan diartikan sebagai penyiapan individu-individu untuk memikul tanggung jawab yang berbeda atau lebih tinggi di dalam organisasi. Pengembangan biasanya berkaitan dengan peningkatan kemampuan intelektual atau emosional yang diperlakukan untuk melaksanakan pekerjaan yang lebih baik. ${ }^{35}$

Menurut Dessler, "training is the process of teching new employees the basic skills they need to perform their jobs. ${ }^{36}$ "Artinya : pelatihan adalah proses mengajarkan karyawan baru mengenai keterampilan dasar yang mereka butuhkan untuk melaksanakan pekerjaan mereka.Sementara itu, menurut Noe:

Training refers to a planned effort by a company to facilitate employees' learning of job-related competencies. These competencies include knowledge, skills, or behaviors that are critical for employees to master the knowledge, skills, and behaviors emphasized in training programs and to apply them to their day-to-day activities. ${ }^{37}$

Pelatihan mengacu pada upaya yang direncanakan oleh perusahaan untuk memfasilitasi belajar karyawan dari pekerjaan yang berhubungan dengan kompetensi. Kompetensi ini mencakup pengetahuan, keterampilan, atau perilaku yang penting untuk kinerja yang sukses. Tujuan dari pelatihan ini bagi karyawan adalah untuk menguasai pengetahuan, keterampilam, dan perilaku yang ditekankan dalam program pelatihan, serta menerapkannya dalam kegiatan sehari-hari mereka.

Pelatihan dan pengembangan sudah dilakukan oleh Madrasah Ibtidaiyah Guppi Attaqwa Ketosari. Latihan dan kegiatan pengembangan Madrasah sudah sering diikuti, akan tetapi kemajuan Madrasah belum nampak perkembangannya. Mungkin untuk ke depannya Madrasah Ibtidaiyah Guppi Attaqwa Ketosari harus menambah metodemetode baru untuk meningkatkan motivasi mengembangkan Madrasah untuk lebih maju.

Menurut Hartini, kebijakan strategis pembinaan dan pengembangan profesi dan karier tenaga kependidikan pada satuan pendidikan yang diselenggarakan oleh pemerintah, pemerintah daerah, atau masyarakat ditetapkan dengan peraturan menteri. ${ }^{38}$ Pemerintah dan pemerintah daerah wajib membina dan mengembangkan

\footnotetext{
${ }^{35}$ Simamora, Op. Cit., hal. 287.

${ }^{36}$ Dessler, Gary, Op. Cit., hal. 308.

${ }^{37}$ Noe, M, Human Resource Management, (New Jersey, Pretince Hill Inc, 2005), hal. 4.

${ }^{38}$ Hartini, A.L, Manajemen Pendidikan, (Yogyakarta: LaksBang Pressindo, 2011), hal. 121.
} 
kualifikasi akademik dan kompetensi guru pada satuan pendidikan yang diselenggarakan oleh pemerintah pusat, pemerintah daerah, dan masyarakat. Satuan pendidikan yang diselenggarakan oleh masyarakat wajib membina dan mengembangkan kualifikasi akademik dan kompetensi tenaga kependidikan. Pemerintah pusat dan pemerintah daerah wajib memberikan anggaran untuk meningkatkan profesionalitas dan pengabdian guru pada satuan pendidikan yang diselenggarakan oleh pemerintah.

Madrasah Ibtidaiyah Guppi Attaqwa Ketosari melakukan beberapa langkah untuk memajukan pengembangan dalam kinerja personalia maupun karyawannya, di antaranya: penilaian prestasi kerja, konseling, disiplin, dan latihan. Melalui beberapa langkah tersebut diharapkan kinerja pegawai di Madrasah Ibtidaiyah Guppi Attaqwa Ketosari dapat meningkat kualitasnya.

\section{Pemeilharaan SDM dalam Meningkatkan Motivasi dan Suasana Religius di MI GUPPI ATTAQWA Desa Ketosari Kecamatan Bener Kabupaten Purworejo}

Pemeliharaan di suatu organisasi atau lembaga sangat penting, salah satu contoh pemeliharaan adalah memberikan kompetensi. Dengan adanya kompetensi prestasi kerja karyawan meningkat, karena kompetensi sebagai motivasi dan kepuasan kerja karyawan adalah melalui kompetensi akan tetapi kompetensi yang diberikan tidak sesuai dengan kinerja para karyawan. Sehingga prestasi kerja, motivasi, dan kepuasan kerja mencoba bisa turun secara dramatis. Karena program kompetnasi merupakan salah satu cara untuk mempertahankan sumber daya manusisa.

Untuk memelihara sumber daya manusia di Madrasah Ibtidaiyah Guppi Attaqwa Ketosari diperlukan beberapa hal di antaranya: pemberian kompensasi, pelayanan karyawan/pegawai, keamanan, dan keselamatan.

Menurut Marihot Tua, (Burhanuddin Yusuf), kompensasi adalah keseluruhan balas jasa yang diterima oleh pegawai sebagai akibat dari pelaksanaan pekerjaan di organisasi dalam bentuk uang atau lainnya, yang dapat berupa gaji, upah, bonus, insetif dan tunjangan lainnya seperti tunjangan kesehatan, tunjangan hari raya, uang makan, uang cuti dan lain-lain. ${ }^{39}$ Pembayaran kompensasi tersebut ada yang dikaitkan langsung dengan kinerja seperti upah atau gaji, bonus dan komisi sehingga

${ }^{39}$ Burhanuddin Yusuf, Manajemen Sumberdaya Manusia di Lembaga Keuangan Syariah, (Jakarta: PT Raja Grafindo Persada, 2015), hal. 136. 
sering disebut dengan kompensasi langsung. Dan ada yang tidak dikaitkan langsung dengan kinerja sebagai upaya meningkatkan ketenangan dan kepuasan kerja seperti tunjangan-tunjangan.

Pemberian kompensasi memang salah satu alat efektif yang digunakan untuk pemeliharaan pegawai. Pemberian kompensasi di MI Guppi At-Taqwa Ketosari dapat memberikan motivasi terhadap kinerja pegawai untuk lebih berprestasi dalam bekerja. Madrasah juga sangat memperhatikan dalam pengetahuan kompensasi secara rasional dan adil agar tidak terjadi kecemburuan sosial antar karyawan. Kendatipun besaran pembiayaan gaji pegawai yang masih minim, namun semangat kerja dan kesungguhan kerja para pegawai terus terjaga.

Selanjutnya, dalam memelihara hubungan kerja para pegawai, MI Guppi AtTaqwa juga membangun komunikasi yang baik. Iklim yang harmonis juga tampak di madrasah tersebut. Dengan demikian, kendatipun secara financial apa yang didapat pegawai sedikit, namun hubungan kerja tetap terjaga baik. Pemeliharaan hubungan kerja para pegawai sudah baik.

\section{Penggunaan SDM dalam Meningkatkan Motivasi dan Suasana Religius di MI GUPPI ATTAQWA Desa Ketosari Kecamatan Bener Kabupaten Purworejo}

Penggunaan SDM atau pegawai di Madrasah Ibtidaiyah Guppi At-Taqwa Ketosari dilakukan dengan perencanaan karir dan perluasan pekerjaan. Dalam penggunaan SDM, madasah tersebut juga melakukan pembinaan rutin. Menurut Sismiati, pembinaan dilakukan dalam uapaya mengelola dan mengendalikan pegawai selama melaksanakan kerja di lembaga/sekolah. ${ }^{40}$ Pendidikan dan pelatihan merupakan upaya peningkatan pegawai agar lebih berkualitas kinerjanya. Pendidikan dan pelatihan dimaksudkan sebagai pengembangan bagi tenaga kependidikan. Pendidikan dan pelatihan dalam contoh memberikan kesempatan kepada seluruh staf untuk mengikuti penataran, melanjutkan pendidikan, seminar, workshop, dan lain-lain.

MI Guppi At-Taqwa Ketosari menyadari betul bahwa SDM merupakan aset penting bagi kemajuan madrasah yang hatus dijaga dengan baik. Berbagai usaha dan pengoptimalan penggunaan tenaga pendidik juga telah dilakukan. Pemanfaatan SDM

\footnotetext{
${ }^{40}$ Sismiati Atiek, Op. Cit.
} 
dalam upaya pencapaian visi misi sekolah telah dilakukan dengan baik. Hal tersebut merupakan langkah efektif guna peningkatan kemajuan madrasah.

\section{KESIMPULAN}

Berdasarkan analisis data dan pembahasan yang diperoleh dalam penelitian ini, maka dapat diambil kesimpulan sebagai berikut:

1. Penarikan SDM dalam Meningkatkan Motivasi dan Suasana Religius di MI Guppi At-Taqwa Desa Ketosari Kecamatan Bener Kabupaten Purworejo belum maksimal. Dalam merekrut tenaga pendidikan masih menggunakan cara-cara sederhana dan masih menggunakan cara-cara lama. Dalam proses penarikan SDM di MI Guppi Attaqwa Ketosari hanya mengambil beberapa langkah, baik secara eksternal dan internal yang digunakan. Dalam merekrut tenaga pendidik belum sitematis, karena tidak secara keseluruhan langkah proses penarikan yang tepat dilakukan.

2. Seleksi SDM dalam Meningkatkan Motivasi dan Suasana Religius di MI Guppi AtTaqwa Desa Ketosari Kecamatan Bener Kabupaten Purworejo dilakukan Madrasah Ibtidaiyah Guppi Attaqwa Ketosari di antaranya: Penerimaan pendahuluan pelamar, Tes-tes penerimaan, Wawancara seleksi, Pemeriksaan referensi, dan Evaluasi medis, Wawancara atasan langsung, dan Keputusan penerimaan. Dalam proses seleksi SDM, MI Guppi At-Taqwa Ketosari telah menerapkan langkah-langkah yang sistematis. Kendatipun dalam pelaksanaannya belum optimal, namun nyatanya dapat terlaksana.

3. Pengembangan SDM dalam Meningkatkan Motivasi dan Suasana Religius di MI Guppi At-Taqwa Desa Ketosari Kecamatan Bener Kabupaten Purworejo dilakukan dengan mengadakan pelatihan dan pembinaan untuk senantiasa belajar dan mengembangkan kompetensi diri madrasah. MI Guppi At-Taqwa Ketosari juga melakukan beberapa langkah untuk memajukan pengembangan dalam kinerja personalia maupun karyawannya, yaitu melalui: Penilaian prestasi kerja, Bimbingan dan konseling, Pembinaan kedisiplinan, dan Pelatihan.

4. Pemeliharaan SDM dalam Meningkatkan Motivasi dan Suasana Religius di MI Guppi At-Taqwa Desa Ketosari Kecamatan Bener Kabupaten Purworejo dilakukan melalui beberapa hal, di antaranya yaitu: pemberian kompensasi, pelayanan 
karyawan, keamanan dan keselamatan. Itu semua diperhatikan oleh madrasah guna pemeliharaan hubungan kerja yang baik. (a) MI Guppi At-Taqwa Ketoasri dalam memberikan kompensasi terhadap karyawanya di antaranya: Evaluasi pekerjaan, Pengupahan, Program-program insentif, dan kompensasi pelengkap. (b) Beberapa pelayanan karyawan yang sudah dilaksanakan di MI Guppi At-Taqwa Ketosari antara lain: Program-program rekreasi, Cuti, dan Aneka ragam pelayanan lain. (c) Keamanan dan keselamatan karyawan di MI Guppi At-Taqwa Ketosari dijamin dan didukung oleh lingkungan masyarakat sekitar madrasah.

5. Penggunaan SDM dalam Meningkatkan Motivasi dan Suasana Religius di MI Guppi At-Taqwa Desa Ketosari Kecamatan Bener Kabupaten Purworejo di antarannya: Perencanaan karir dan Perluasan pekerjaan. Selain itu juga dengan memberikan peluang seluas-luasnya kepada karyawan untuk mengembangkan berbagai macam karier untuk mencapai rencana-rencana mereka untuk lebih maju dan bisa bersaing di masa yang akan datang. (a) Pendidikan dan pelatihan sudah dilakukan selama ini dalam peningkatan karier pegawai, di antaranya mengikuti penetapan, melanjutkan pendidikan, seminar, workshop, dan lain-lain. (b) Perluasan pekerjaan di Madrasah Ibtidaiyah Guppi At-Taqwa Ketosari dimulai dari diri pegawai. Setelah komitmen pribadi dibuat, maka beberapa kegiatan dapat dibuat. Jika pegawai meningkatkan kemampuan, misal melalui program latihan, pengambilan kursus-kursus atau penambahan gelar, maka berarti mereka memanfaatkan kesempatan untuk tumbuh.

\section{DAFTAR PUSTAKA}

Burhanuddin Yusuf, 2015. Manajemen Sumberdaya Manusia di Lembaga Keuangan Syariah, Jakarta: PT Raja Grafindo Persada.

Daft, Richard L, 2010. Era Baru Manajemen, Edisi 9, Buku 2, Jakarta: Salemba Empat Dessler, Gary, 2011. Manajemen sumber daya manusia. Jakarta: Indkes.

Dubois, 2004. Competency-Based Human Resource Management, (Mountain View, California: Davies-Black Publising.

Handoko, T. Hani, 2014, Manajemen. Edisi Kedua. Yogyakarta: BPFE Yogyakarta.

Hasibuan, 2011, Manajemen Sumber Daya Manusia, Jakarta: Bumi Aksara.

Hartini, A.L, 2011. Manajemen Pendidikan, Yogyakarta: LaksBang Pressindo. 
Indah Ivonna, dkk, 2013. Pendidikan Budi Pekerti, Yogyakarta: Kanisius.

Isjoni. 2009. Pembelajaran Kooperatif. Pekanbaru: Pustaka Pelajar.

Manullang, M .2012. Manajemen Sumber Daya Manusia. Jakarta: Ghalia Indonesia.

Mathis, R.L. \& J.H. Jackson. 2001. Human Resource Management: Manajemen Sumber. Daya Manusia. Terjemahan Dian Angelia. Jakarta: Salemba Empat.

Mondy R. W \& Shane, R., 1999. Management, New Jersey: Pretince Hill Inc.

Muhaimin. 2006, Nuansa Baru Pendidikan Islam, Jakarta: PT Raja Grafindo Persada.

Ngainun Naim, 2012. Character Building. Yogyakarta: Arruz Media.

Noe, M, 2005. Human Resource Management, New Jersey, Pretince Hill Inc.

Nurcholish Madjid, 2010. Masyarakat Religius. Jakarta: Dian Rakyat.

Patton, Michael Quinn. 2006. Metode Evaluasi Kualitatif. Yogyakarta: Pustaka Pelajar.

Peraturan Pemerintah No 19 Tahun 2005 tentang Standar Nasional Pendidikan.

Rivai, Veithzal dan Ella Jauvani Sagala, 2009. Manajemen Sumber Daya Manusia untuk Perusahaan. Edisi Kedua, Jakarta: Raja Grafindo Persada.

Sedarmayanti, 2009, Sumber Daya Manusia dan Produktivitas Kerja, Bandung: Mandar Maju.

Silalahi, Ulber, 2002. Pemahaman praktis azas-azas manajemen. Bandung: Mandar Maju.

Simamora. 2004. Manajemen Sumber daya Manusia, Jakarta: Lentera.

Singodimejo, M, 2000.Manajemen Sumber Daya Manusia,Surabaya: SMMAS.

Sismiati Atiek \& Rugaiyah, 2011. Profesi Kependidikan, Bogor: Ghalia Indonesia.

Sugiyono, 2009, Metode Penelitian Pendidikan, Bandung: Alfabeta.

Yusriani. 2012. Implementasi Manajemen Sumber Daya Manusia: Tenaga Pendidik dan Kependidikan untuk Meningkatkan Mutu Layanan Pendidikan. Al-Ulum. Vol.1 No.1. 